\title{
タンタル酸リチウム薄膜の湿式作製とその感湿素子としての利用
}

\author{
井本文夫・七滝＼cjkstart努・塩崎克幸・岩本仁志 - 山本達夫* \\ $\left(\begin{array}{lll}\text { 静岡大学 } & \text { 工学部 } & \text { 工業化学科 } \\ * \text { 静岡大学 } & \text { 電子工学研究所 }\end{array}\right)$
}

\section{Preparation of Lithium Tantalate Thin Films by Wet Process and Its Application to a Moisture-Sensitive Device}

Fumio IMOTO, Tsutomu NANATAKI, Katsuyuki SHIOZAKI, Hitoshi IWAMOTO and Tatsuo YAMAMOTO*

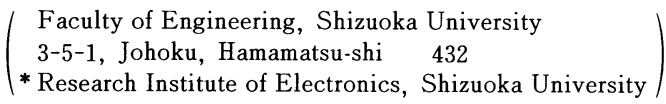

Thin film of lithium tantalate was prepared by the dipping process from double alkoxide of the corresponding composition. SEM-observations and the X-ray diffraction analyses showed that the film consists of a pile of micro-particles $(200-300 \AA$ in diameter), and that the particles are amorphous when baked at $450^{\circ} \mathrm{C}$ or below and poly-crystalline when baked at $480^{\circ} \mathrm{C}$ or above. These two phases showed a marked difference in Raman spectra. The amorphous film showed ionic conductivity. Behavior of the amorphous film as a moisture-sensitive device was investigated. Surface ac-resistivity of an element $(3.2 \times 3.2$ $\mathrm{mm}, 1 \mu \mathrm{m}$ thick with a pair of comb-type electrodes) covered the range $10^{7}-10^{4} \Omega$ at the relative humidities of $25-90 \%$. Reproducibility of the resistivity in the repeated cycles of the humidity was good, temperature-dependence was small and the response time to an abrupt change of humidity was sufficiently high. It was proved that the amorhous film is highly applicable.

[Received July 1, 1986 ; Accepted October 14, 1986]

Key-words : Preparation of thin film, Lithium tantalate, Alkoxide, Amorphous, Poly-crystal, Moisture-sensitive device

\section{1. 緒言}

金属アルコキシドの加水分解及び熱分解を利用した酸 化物薄膜の作製法は，組成制御が容易で処理温度が低い という特徵をもつほか, 膜をアモルファスにも多結晶に もなしうることから，各種の特性を賦与できることが期 待される. 特に通常の雾囲気中で操作できるため生産性 に優れ, またどのような種類, 形状, 寸法の基板にも適 用が可能であるなど，実用面でも有利である。

この方法により，既に 2 価以上の金属の酸化物及び複 合酸化物の膜が作製されており ${ }^{1), 21}, 2$ 価と 4 価の組み 合わせのほとんどについて, 複合酸化物透明薄膜の作製 が可能となっている3). しかし，1価と 5 価の組み合わ せについては報告がなされていない.

当研究室では, アルカリ金属 $(\mathrm{Li}, \mathrm{Na}, \mathrm{K})$ と $\mathrm{Nb}$ 又 は Ta との組み合わせによる金属酸化物薄膜の作製につ いて報告した ${ }^{4)}$ が，その後特に $\mathrm{LiTaO}_{3}$ 薄膜の作製及び その電気的特性について詳細に検討した。なおこの $\mathrm{LiTaO}_{3}$ 薄膜が多孔性であることに着目し，薄膜型湿度 センサーとしての利用についても検討したので併せて報 告する.

\section{2. 実 験}

\section{1 薄膜の作製}

複合アルコキシド $\operatorname{LiTa}(\mathrm{OEt})_{6}$ は Mehrotra ${ }^{5)}$ の方 法により合成した. すなわち市販の特級試薬 $\mathrm{Ta}(\mathrm{OEt})_{5}$ のエチルアルコール溶液中に等モルの金属リチウムを加 えてかくはんし, 水素の発生が終了してから 6 時間還流 して反応を完結させた. 溶媒を留去して得た $\mathrm{LiTaO}_{3}$ (白 色固体）を酸化物として 15～20\%になるようメ夕ノ一 ルに溶解し，急激な加水分解を抑制するため等モルのア セト酢酸エチルを添加して浸漬用溶液とした.

基板としては, 表面粗度 $0.5 \mu \mathrm{m}$ 程度のアルミナ板又 はコーニング No.7059 のガラス板を用い, 上記の溶液 に浸漬塗布し, 乾燥後 $450^{\circ} \sim 600^{\circ} \mathrm{C}$ の所定温度で大気中 30 分間焼成して酸化物薄膜を作製した. 膜厚は，ガラ ス基板の場合についてのみ多重反射干渉法により測定し た.

薄膜の構造は, X 線回折装置（理学電機製新型，薄 膜回折装置付き), ラマン散乱分光装置 (日本分光製レー ザーラマン分光光度計 R-300), SEM（日本電子製走査 型電子顕微鏡 T-300）などによって調査測定した.

\section{2 薄膜の電気的特性の測定}

導電膜（10 $\Omega / \square の$ ITO 膜）付きガラス基板上に作 製した薄膜の表面に金電極 $\left(10 \mathrm{~mm}^{2}\right)$ を蒸着し, パイレッ クスガラス製测定管中 $0.133 \mathrm{~Pa}$ の減圧下, $25^{\circ} \sim 450^{\circ} \mathrm{C}$ の範囲 (昇温速度 $5^{\circ} \mathrm{C} / \mathrm{min}$ ) で厚さ方向の電気特性を 


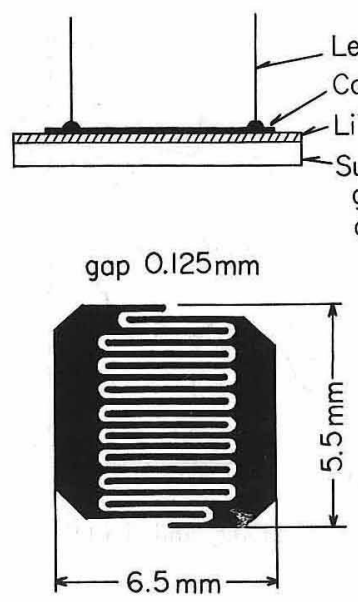

Fig.1. Schematic diagram of the moisture-sensitive device.

測定した.

直流導電率は安定化電源装置を用いて試料に一定電圧 を印加し，電流值を読み取ることによって測定した，膜 の絶縁破壊を起こさぬよう, 印加電圧は $0.4 \mathrm{~V}$ 以下に とゼめた。

交流測定は，扶桑製作所製定電位電解装置 311 , 発振 器-帯域沪波器 331 , 位相敏感検波器 332 を用いて周波 数 50 1 $10^{4} \mathrm{~Hz}$ の範囲で同期整流法によって武料のコンダ クタンス $G$ 及びサセプタンス B を測定した．印加電圧 は $10 \mathrm{mV}$ である.これらの測定值を（1）式によりレ ジスタンス $R$ 及びリアクタンス $X$ に変換し, 複素イン ピーダンス法によって交流導電率を求めた.

$$
R=G /\left(G^{2}+B^{2}\right), X=-B /\left(G^{2}+B^{2}\right)
$$

また誘電率 $\varepsilon_{\mathrm{r}}$ は, 試料が抵抗之容量の並列等価回路 で近似できるとして (2) 式により算出した.

$$
\varepsilon_{\mathrm{r}}=C_{\mathrm{p}} t / \varepsilon_{0} S=B t / \varepsilon_{0} \omega S
$$

ただし， $t$ は試料膜厚 $(\mathrm{m}), S$ は電極面積 $\left(\mathrm{m}^{2}\right), \varepsilon_{0}$ は 真空誘電率 $\left(\mathrm{F} \cdot \mathrm{m}^{-1}\right), C_{\mathrm{p}}$ は等価並列容量 $(\mathrm{F}), \omega$ は 角周波数である.

\section{3 感湿素子の作製と感湿特性の測定}

基板上に作製した薄膜の上部にメタルマスクを通して 金のくし型電極 (ギャップ幅 $0.125 \mathrm{~mm}$ ) を蒸着し,リー ド付けして感湿素子を構成した（図 1 ). 基板上にこの 電極を直接蒸着した後に薄膜をつける場合を下部電極型 と称し，上述の上部電極型と区別した，素子をエタック 製温湿試験槽（JLH-300）内に挿入し，槽内の相対湿 度 $(\mathrm{RH})$ を変化させて, 素子の並列抵抗 $R_{\mathrm{p}}$ 及び並列 容量 $C_{\mathrm{p}}$ の変化を LCR メーター (YHP-4265 A) に上 り測定した。

\section{3. 結果及び考察}

\section{1 薄膜の作製とその構造}

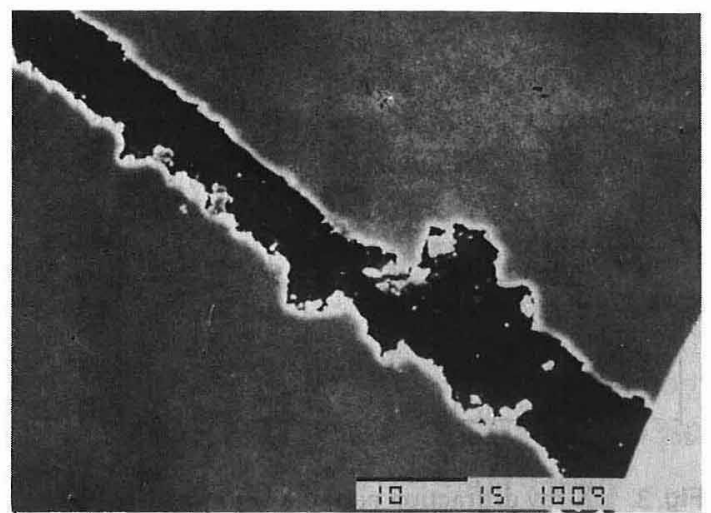

(a) Baked at $450^{\circ} \mathrm{C}$, on glass substrate

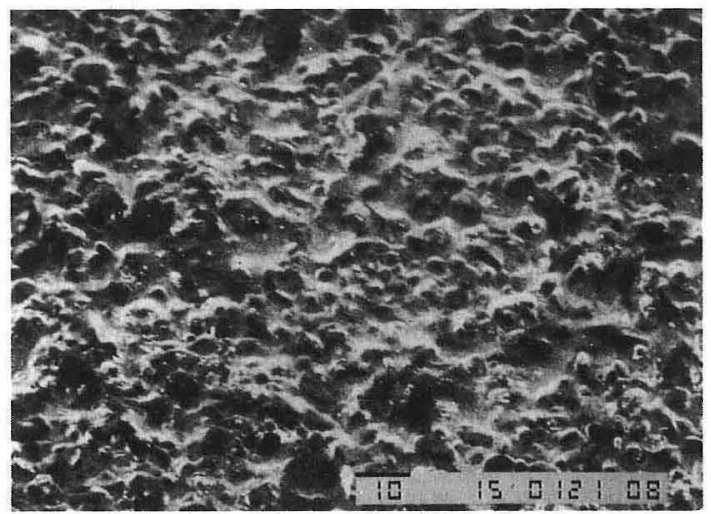

(b) Baked at $450^{\circ} \mathrm{C}$, on alumina substrate

Fig. 2. Selected SEM pictures of $\mathrm{LiTaO}_{3}$ films prepared by dipping process.

複合アルコキシド LiTa $(\mathrm{OEt})$ 。 のエトキシ基の一部

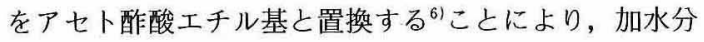
解に対して安定な浸漬用溶液を得て健全な透明薄膜を得 ることができた. 熱重量分析の結果より, 膜の熱分解過 程はほぼ $450^{\circ} \mathrm{C}$ で終了することが分かった.

1 回の塗布による膜厚と引き上げ速度との間には，両 対数軸で直線関係があると言われており7, 引き上げ速 度が大きいほど厚くなるが，本研究における $0.1 〜 0.3$ $\mu \mathrm{m}$ の範囲では単純な直線関係之みなしうる. 焼成後厚 さが $0.3 \mu \mathrm{m}$ 以上になると焼成時に亀裂を生じやすく, 特にアルミナ基板上では表面粗さの関係で $0.1 \mu \mathrm{m}$ が限 界であった. 所定の厚さは塗布・焼成を繰り返すことに よって得られた。

図 2 に薄膜表面の SEM 写真を示す.（a）はガラス 基板上, ( b ) はアルミナ基板上の薄膜で, いずれも $450^{\circ} \mathrm{C}$ で焼成した. ガラス基板上の薄膜は故意に傷を付 けて示したが, 均一で骬らかな外観を示すのに対し, ア ルミナ基板上では表面の凹凸が膜にも影響していること がうかがわれる. しかし両膜とも亀裂やピンホールを含 まず, 200 300 A の微粒子の積層からなる多孔質膜で あることが分かる. 


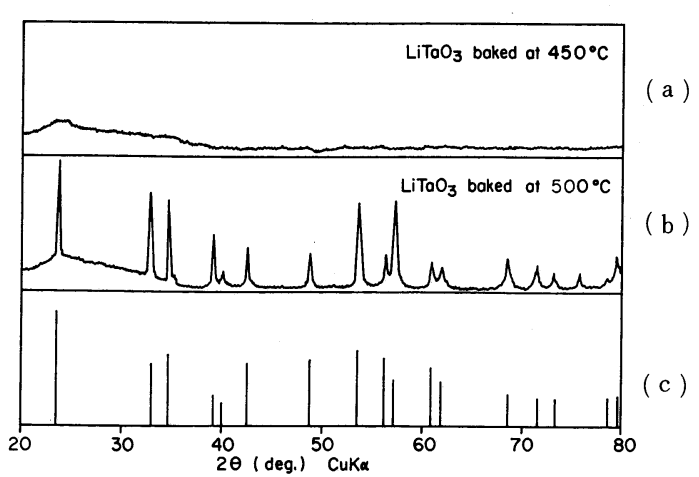

Fig. 3. X-ray diffraction patterns of $\mathrm{LiTaO}_{3}$ dip films. The bottom diagram : JCPDS File, No. 29-0836

図 3 に薄膜の $\mathrm{X}$ 線回折図形を示す. $450^{\circ} \mathrm{C}$ 焼成膜 ( a ) は $\mathrm{X}$ 線的にアモルファスであるが, $500^{\circ} \mathrm{C}$ 焼成膜 $(\mathrm{b}$ ) は結晶化がかなり進行しており， (c) の $\mathrm{LiTaO}_{3}$ 標準 パターン ${ }^{8)}$ とよく一致している. なお, 薄膜回折装置を つけない通常法で測定すると, 各ピークの強度比が変則 的であった。しかし，特定の配向性が見られるわけでは なく, 要は薄い膜に通常法が適していないのであろう. $480^{\circ} \mathrm{C}$ 焼成膜においても $\mathrm{LiTaO}_{3}$ 多結晶の回折ピーク位 置にブロードな山が観察され, 結晶化の開始温度は $450^{\circ} \mathrm{C}$ から $480^{\circ} \mathrm{C}$ の間にあるものと判断された。

更に別の立場から薄膜構成物の構造を検討するため, ラマン散乱の測定を行った（図 4). $450^{\circ} \mathrm{C}$ 焼成膜は $\mathrm{Ta}_{2} \mathrm{O}_{5}$ 多結晶に類似した散乱を示し, $\mathrm{LiTaO}_{3}$ 多結晶と は異なったパターンであった。すなわち, $\mathrm{LiTaO}_{3}$ 多結 晶に見られる $600 \mathrm{~cm}^{-1}$ 付近の散乱ピークが $450^{\circ} \mathrm{C}$ 焼成膜 には見られない。このピークは $\left[\mathrm{TaO}_{6}\right]$ 八面体が $\mathrm{Li}$ の 存在場の影響を受けた場合の $\mathrm{Ta}-\mathrm{O}$ 結合に基づく散乱 ピークと考えられることから, $450^{\circ} \mathrm{C}$ 焼成膜中の個々の 粒子の結晶構造は $\left[\mathrm{TaO}_{6}\right]$ 八面体を基本とするものの, 八面体同士の結合形式に規則性を欠いてやや広がった構 造となり, その中に化学量論比の $\mathrm{Li}$ がほぼ均一に分布

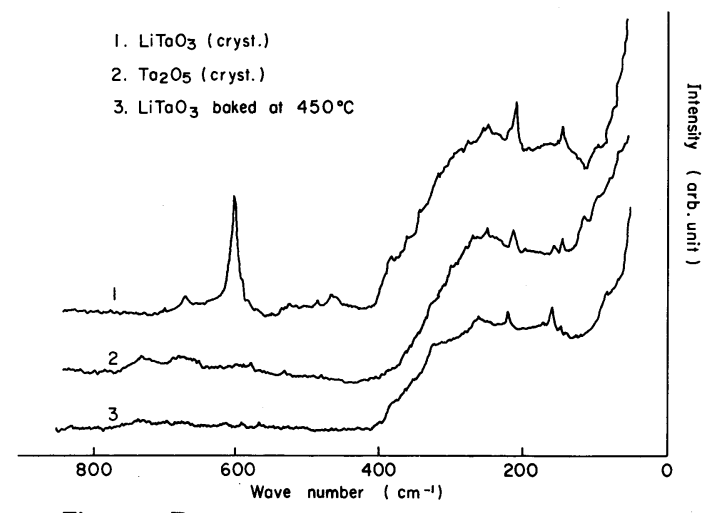

Fig. 4. Raman spectra of $\mathrm{LiTaO}_{3}$ and $\mathrm{Ta}_{2} \mathrm{O}_{5}$.

した，いわば結晶の前駆体のようなものになっているの であろう.

このような個々の微粒の表面には, なお微量の $\mathrm{OH}$ 基が残留して粒界を構成しているが，焼成温度の上昇に 伴って粒界が消失し, 基本構造のち密化が進んで多結晶 に移行していくものであろう.

\section{2 薄膜の電気的性質}

アモルファス膜 $\left(450^{\circ} \mathrm{C}\right.$ 焼成) と多結晶膜 $\left(500^{\circ} \mathrm{C}\right.$ 焼 成) の直流導電率は, それぞれ $10^{-12}$ と $10^{-13} \mathrm{~S} \cdot \mathrm{cm}^{-1}$ の オーダーであった。この測定は, 試料の両面に不活性電 極を密着させ, 分解電圧以下の電圧を印加して定常状態 に達した後に電流值を求めたもので, 両膜とも電子伝導 性はほとんゼないものと見られる.

図 5 にアモルファス膜の複素インピーダンスプロット

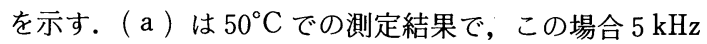
以上の周波数帯域では図のように半円上にプロットされ ている.この半円は抵抗と容量の並列回路に起因するも ので，この場合の真の抵抗値 $R$ は，半円の実軸上での 交点（低周波数側）によって求められる.（b）は $350^{\circ} \mathrm{C}$ での測定で, $50^{\circ} \mathrm{C}$ に見られたような半円は存在 せず，電極と膜の界面の二重層容量による虚数部分の立
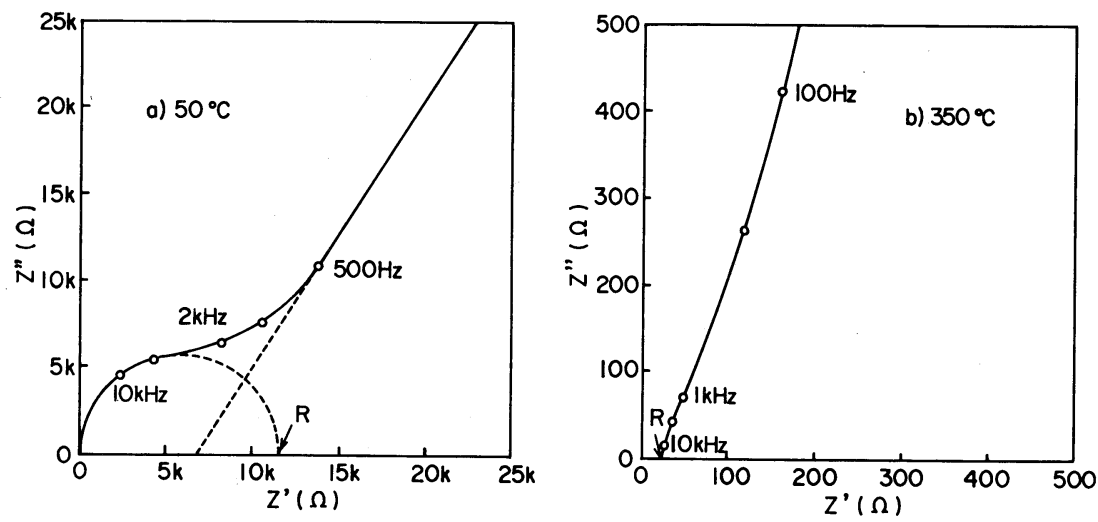

Fig. 5. Complex impedance plots of $\mathrm{LiTaO}_{3}$ film baked at $450^{\circ} \mathrm{C}$.

(a) Measured at $50^{\circ} \mathrm{C}$, (b) Measured at $350^{\circ} \mathrm{C}$ 
ち上がりのみからなっている。これは温度上昇によるイ オンの移動度の増大に基づくもので，このときの真の抵 抗值 $R$ はより高い周波数での值で与えられる.

多結晶膜についても同様の方法によって真の抵抗值を 求めた。この結果, $25^{\circ} \mathrm{C}$ における交流導電率はアモル ファス膜で $5 \times 10^{-8} \mathrm{~S} \cdot \mathrm{cm}^{-1}$, 多結晶膜で $1 \times 10^{-11} \mathrm{~S} \cdot \mathrm{cm}^{-1}$ であった．このような導電率の大きな違いは， $\left[\mathrm{TaO}_{6}\right]$ 八面体とリチウムイオンとの結合の強さに対応するもの で, 上述のアモルファス膜によるラマン散乱の説明を裏 付けるものである.

一般にセラミック半導体や絶縁体では, 温度の上昇と ともに導電率が増大する NTCR 特性を示すが, 特にイ オン導電体の場合, 導電率の温度依存性は ( 3 ) 式によっ て表わされる.

$$
\sigma T=\sigma_{0} \exp (-E / k T)
$$

ここで $\sigma_{0}$ は定数, $k$ はボルツマン定数, $T$ は絶対温度, $\sigma$ はイオン導電率, $E$ は導電の見掛けの活性化エネル ギーである.この式に従って交流導電率の温度依存性を 図6にプロットして示した。この図における直線の傾き より,アモルファス膜及び多結晶膜の見掛けの活性化工 ネルギーはそれぞれ $0.40 \mathrm{eV}$ 及び $0.72 \mathrm{eV}$ と計算され た。この違いは 3.1 節に述べたとおりの構造の違いに起 因するものと思われる.すなわちこのようなアモルファ ス状態はガラス状態と同様, 一つの準安定状態で, 処理 温度及び処理時間により構造特性に多少の変化があるも のと想定された。系統的測定はしていないが, 図 6 にお ける直線から外れた上部の測定点は, $450^{\circ} \mathrm{C}, 3$ 時間経

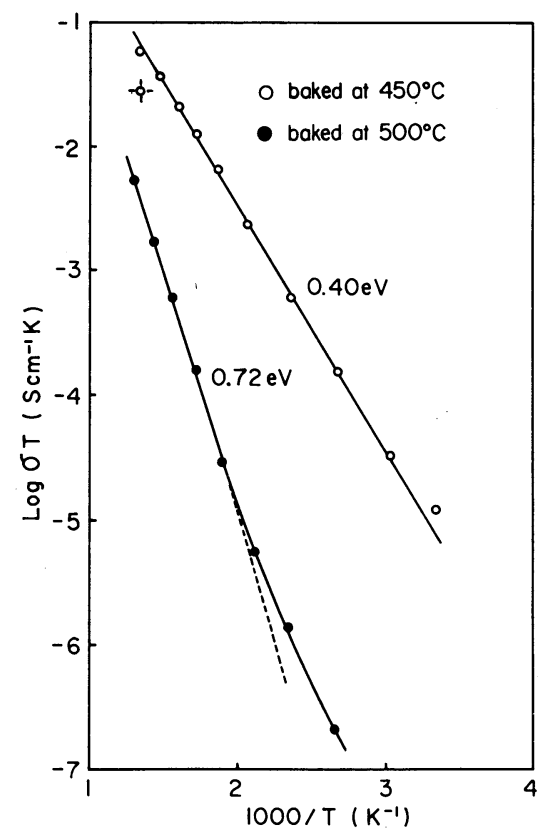

Fig. 6. Temperature-dependence of ac-conductivity of $\mathrm{LiTaO}_{3}$ films (log $\sigma T$ vs. $1 / T$ plots).
過後に測定したもので, 構造の緊密化の影響が現れたも のと考えられる。なお結晶化物でも， $480^{\circ} \mathrm{C}$ 焼成の場合 は，処理時間による変化が同様に観測されている.

図７に導電率の温度依存性を示す。アモルファス膜の 誘電率は低温においても周波数分散が見られ，すべての 周波数において $425^{\circ} \mathrm{C}$ で極大值を示し, 高温低周波数 域 $(1 \mathrm{kHz}$ 以下 $)$ では $10^{4}$ 以上の高誘電率を示した。こ のように結晶化温度付近で誘電率が極大を示す現象は, 超急冷タンタル酸リチウム ${ }^{9)}$ や，二オブ酸リチウムのア

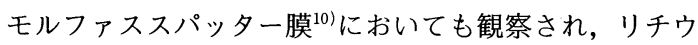
ムイオン伝導による共通現象として理解される.

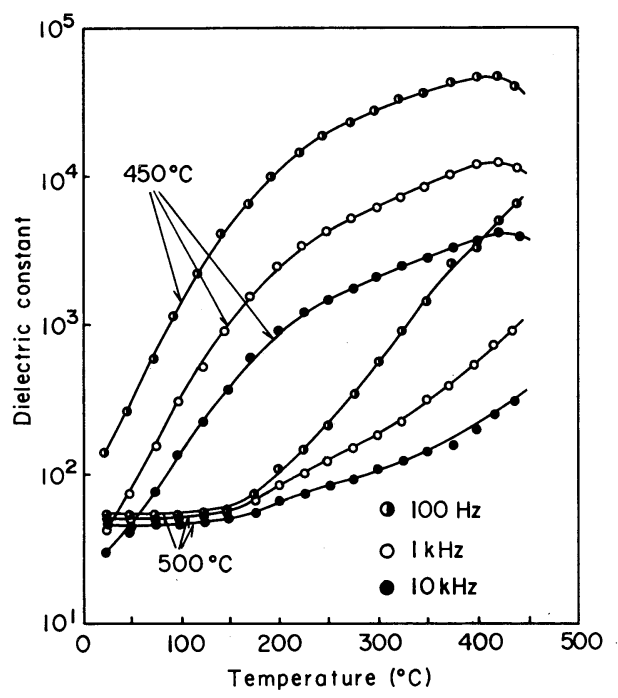

Fig. 7. Temperature-dependence of dielectric constant of $\mathrm{LiTaO}_{3}$ films measured at $100 \mathrm{~Hz}, 1 \mathrm{kHz}$ and $10 \mathrm{kHz}$.

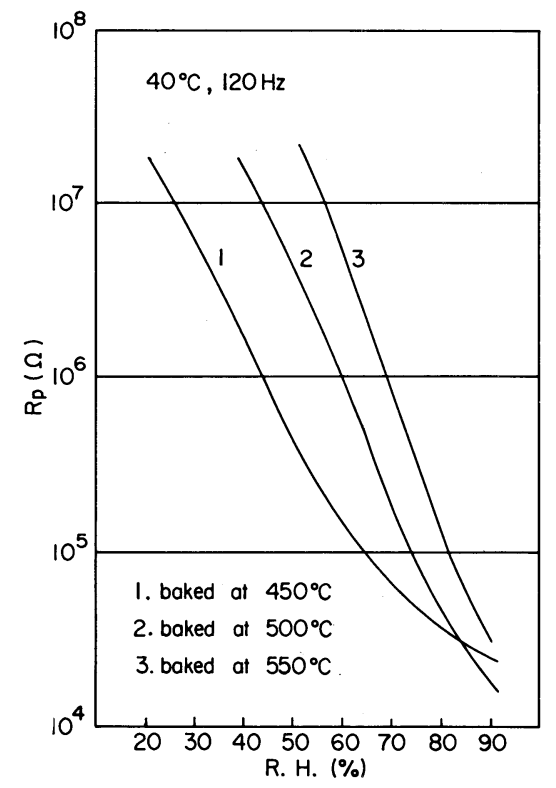

Fig. 8. Variation of electrical resistance with relative humidity $(1 \mu \mathrm{m}$ on glass, upper electrode). 
F. IMOTO et al. 64

\section{3 薄膜の感湿特性}

図 8 に感湿素子 (ガラス基板, 上部電極型) の RH (相 対湿度）の変化に対応する抵抗変化を示す.アモルファ ス膜は $25 \% \mathrm{RH}$ で $10^{7} \Omega$ の表面抵抗を示したものが加 湿に伴って減少し, $90 \% \mathrm{RH}$ で $10^{4} \Omega$ と約 3 けた変化す る良好な感湿特性を示した。これに対し膜の焼成温度が 高くなるにつれて低湿度側での抵抗值は増大し, 実用的 測定範囲（10 8 以下）を超える結果となった。これは

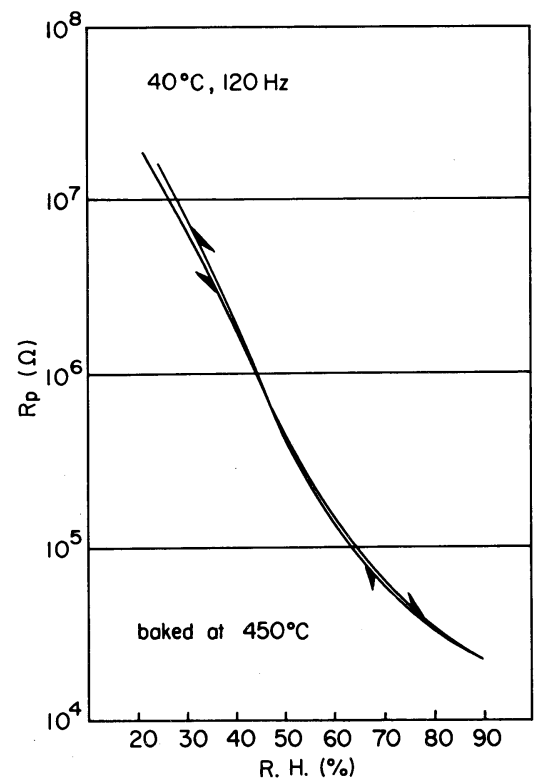

Fig. 9. Hysteresis curve of humidity-dependence of electrical resistance ( $1 \mu \mathrm{m}$ on glass, upper electrode).

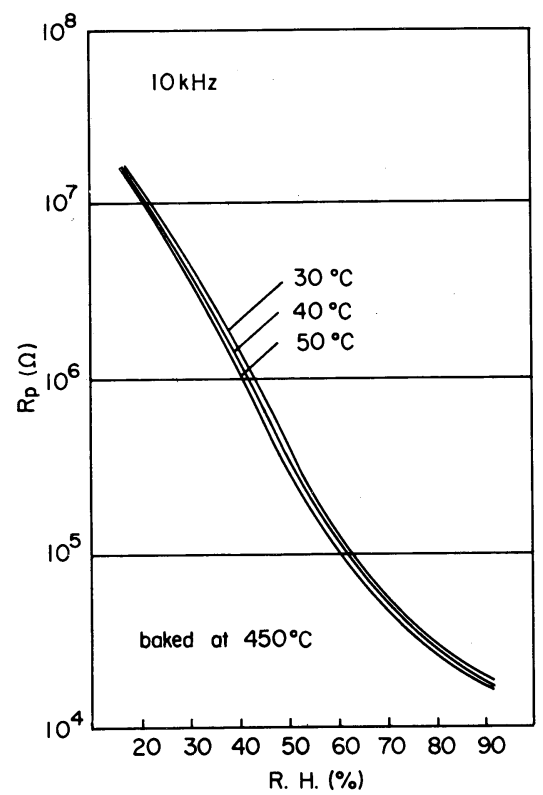

Fig. 10. Variation of electrical resistance with relative humidity at various temperature ( $1 \mu \mathrm{m}$ on glass, upper electrode).
膜の結晶性が増してリチウムイオン伝導が失われたため と考えられる.アルミナ基板を使用した場合もほぼ同様 の結果を示した. 以上より多結晶膜は感湿素子として不 適当と判断し, 以下の感湿特性の測定はすべてアモル ファス膜について行ったものである.

図 9 は感湿素子 (ガラス基板, 上部電極型) の加湿・ 除湿サイクル $(20 \% \mathrm{RH} \leftrightarrow 95 \% \mathrm{RH})$ における抵抗值 のヒステリシス特性を示している. 高湿度域では $\mathrm{RH}$ で $1 \%$, 低湿度域では $2 \%$ のヒステリシスを示したが, 実用上問題のない程度と思われる。

次に槽内温度を $30^{\circ}, 40^{\circ}, 50^{\circ} \mathrm{C}$ と変えて同様の測定 を行い図 10 に示した. 最高 $4 \% \mathrm{RH}$ 程度の違いはあっ たが, 温度依存性は小さいことが分かった。これはアモ ルファス膜の導電の活性化エネルギーの小さいことから

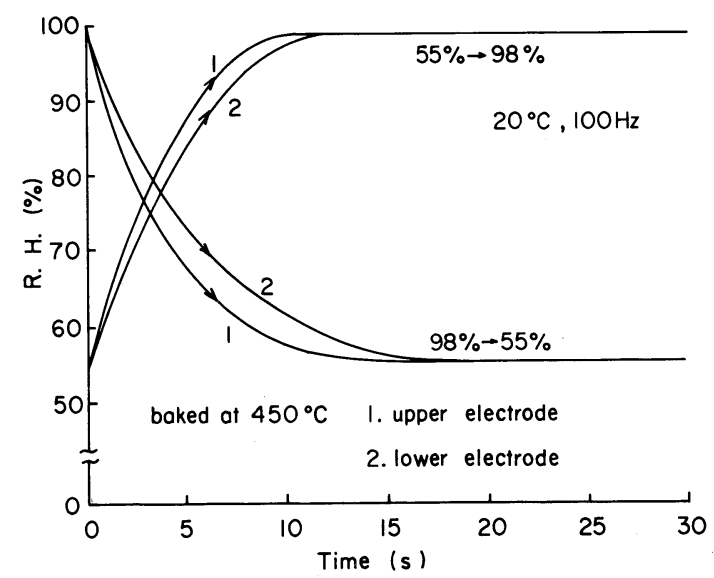

Fig. 11. Response time to sudden change of relative humidity $(1 \mu \mathrm{m}$, on alumina substrate).

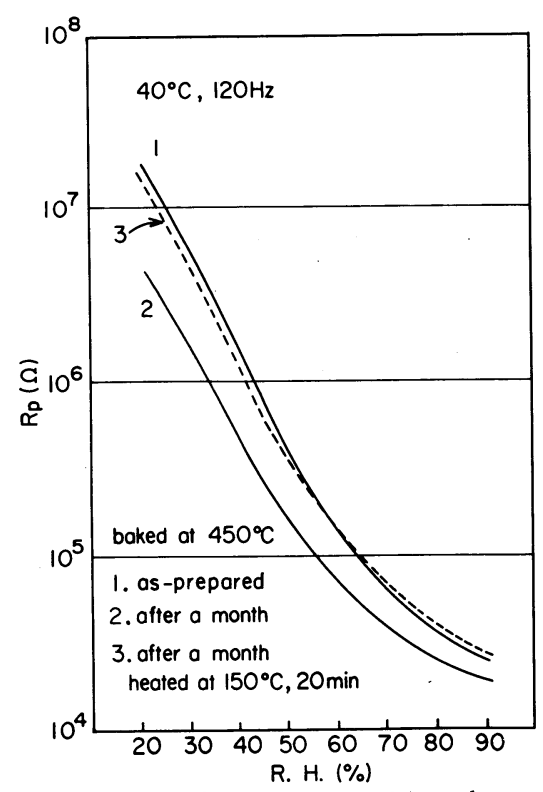

Fig. 12. Variation of moisture-sensitive characteristic after aging ( $1 \mu \mathrm{m}$ on glass, upper electrode). 
も予想されたところである。

図 11 に感湿素子(アルミナ基板, 上部及び下部電極型) の応答特性を示す。すなわち, $98 \% \mathrm{RH}$ の試験槽に約 $55 \% \mathrm{RH}$ の大気雾囲気から試料を出し入れすることに より，抵抗值が平衡に達するまでの経過を観測したわけ である．上部電極型（1）の増湿応答時間は 10 秒，減 湿応答時間は 14 秒であるのに対し，下部電極型（2） ではそれぞれ 2 3 秒の遅れが加わっている：これより， 水蒸気は多孔質膜中を速やかに拡散するため, 電極が膜 で覆われていても応答時間には大きな差がないことが分 かった．また，これらの值はいずれも実用上適当なもの と考えられる.

図 12 に標準的な方法で作製した感湿素子の経時変化 を示した．室内放置 1 か月後の素子について测定した感 湿特性曲線（2）は, 初期のそれ（1）に比べて全般的 に抵抗値として半けた程度低下していることが分かる.

一般にセラミック湿度センサーと呼ばれるものの感湿 特性における経時変化は高抵抗化を示すものが多いが, その原因は，主成分である不定比酸化物 $\left(\mathrm{ZnO}, \mathrm{Cr}_{2} \mathrm{O}_{3}\right.$, $\mathrm{SnO}_{2}, \mathrm{TiO}_{2}$ なよ゙）に対する添加成分の原子価制御効果 によって生じた荷電担体（電子又は正孔）の数が，時間 の経過とともに表面に吸着した水酸基や酸素の影響を受 けて減少するためと考えられる.これに対し,アモルファ ス $\mathrm{LiTaO}_{3}$ からなる感湿素子の経時変化が低抵抗化を示 す理由は，その導電機構の違いに基づいて説明されなけ ればならない。

すなわち，本研究における薄膜素子は 3.1 節及び 3.2 節に述べたとおり $\mathrm{Li}^{+}$イオンを荷電担体とする固体電 解質であるが，この基本的なイオン伝導に加えて， $\mathrm{LiTaO}_{3}$ の粒界に化学吸着された水分子が $\mathrm{Li}^{+}$イオンの 影響を受けてより動きやすいプロトン $\mathrm{H}^{+}$を生成するも のと考えられる.

\section{$\mathrm{Li}^{+}+\mathrm{H}_{2} \mathrm{O} \rightleftarrows \mathrm{LiOH}+\mathrm{H}^{+}$}

更に，その表面に物理吸着した水分子の量に応じて導 電率が変化し，センサーとしての機能を果たすのである が，上記の反応は表面がある程度安定化するまで進行し て, ベースとしての抵抗值の低下をきたすものと考えら れる.

なお，このように変化した素子を, 大気中で $150^{\circ} \mathrm{C}$, 20 分間加熱することにより，図 12（３）のようにほぼ初 期值に近い特性曲線に回復させることができた.しかし， 更に $40^{\circ} \mathrm{C} ， 95 \% \mathrm{RH}$ のような高湿度雾囲気中に 1 か月 ほよ゙放置した試料の抵抗值は不安定で，加熱処理によっ ても初期值に回復させることができなかった。この場合 は $\mathrm{LiOH}$ の溶液膜が表面に形成されたものと思われる.

以上のように本研究では，目的組成に該当する複合ア モルコキシドを出発物質として, 原子規模の均一性をも つ電解質型の感湿素子を目標として，アモルファス
$\mathrm{LiTaO}_{3}$ の薄膜を作製し，主としてその電気特性を測定 した. 得られた膜は健全で，その特徴ある構造に基づく 幾つかの優れた特性が見いだされた。しかし，経時変化 に関してはなお課題が残されている.

多結晶膜についても検討したが，低湿度側での表面抵 抗值が実用測定範囲 $\left(10^{7} \Omega\right.$ 以下) を超えるため, 詳細 は示さなかった。

\section{4. 総 括}

タンタル酸リチウムの薄膜が, 相当する組成の複合ア ルコキシドから浸漬法によって調製された．SEM 観察 とX 線回折法により，この薄膜は微小粒子 $(200 \sim 300$ A径）の集積からなること，またその粒子の結晶構造は， $450^{\circ} \mathrm{C}$ 以下で焼成されたときはアモルファスに, $480^{\circ} \mathrm{C}$ 以上では多結晶体になることが分かった．ラマンスペク トルを比較すると，両者の間に明確な差異が見られた。 このアモルファス物は結晶質と同様, $\left[\mathrm{TaO}_{6}\right]$ 八面体の 配列を基本とするが，八面体同士の結合様式はやや広 がったものとなり，リチウムイオンは定位置に強く固定 されていないと判断された．また，このアモルファス膜 はイオン伝導性をもつことが確認された.

このアモルファス膜の感湿素子としての挙動が検討さ れた. 素子 $(3.2 \times 3.2 \mathrm{~mm}$ ，厚さ $1 \mu \mathrm{m}$ ，〈し型対電極 付き）の表面交流抵抗值は，相対湿度の $25 \sim 90 \%$ に対 して， $10^{7} \sim 10^{4} \Omega$ の範囲に変化することが示された。ま た, 増湿減湿のサイクルに伴う抵抗值の再現性は良く, 温度依存性も小さく，湿度の急変に対する応答は 10 14 秒と速かった。これらの結果は，この素子の実用性 の高いことを示すものである. しかし，経時変化に関し てはなお課題が残されている.

謝 辞 本研究の遂行に当たり, 原料薬品そのほかについ て格別の御援助を頂いた日本曹達（株）新材料研究室の方々に 厚く御礼申し上げます.

\section{文献}

1）神谷寛一，横尾俊信，表面，24，131-42（1986）.

2）加藤石生, 吉本哲夫，エレクトロニクセラミクス， 16, 41-47 (1985).

3）井本文夫，木村信夫，窯業協会昭和 57 年年会講演予稿集 A-27 (1982) p. 68.

4）井本文夫, 塩崎克幸, 七滝 努, 善業協会昭和 59 年年会 講演予稿集 C-26（1984）p. 221.

5) R. C. Mehrotra, M. M. Agrawal and P. N. Kapoor, J. Chem. Soc. (A), 1968, 2673-76 (1968).

6) R. C. Mehrotra, P. N. Kapoor and S. Prakashi, Aust. J. Chem., 19, 2079-81 (1966).

7) H. Dislich and E. Hussmann, Thin Solid Films, 77, 129-36 (1981).

8) JCPDS File, No. 29-0836.

9) A.M. Glass, M.E. Lines, K. Nassau and J.W. Shiever, Appl. Phys. Lett., 31, 249-50 (1977).

10) M. Kitabatake, T. Mitsuya and K. Wasa, J. Appl. Phys., 56, 1780--84 (1984). 